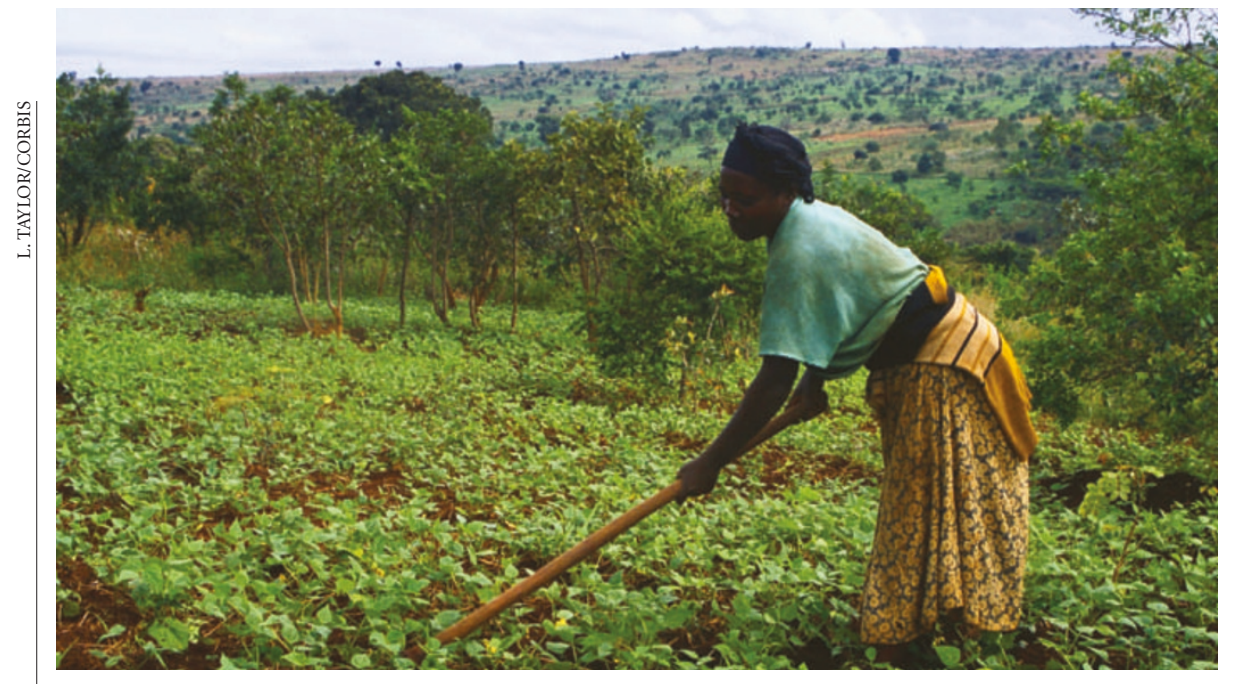

Field work: African subsistence farmers could benefit from more emphasis on agricutural research.

\title{
UN urged to use science in fight against food shortfall
}

Helen Pearson, New York

Africa should pursue agricultural research more avidly in order to feed its growing population, scientific academies have told the United Nations. But the academies' recommendations are some way from filling empty bellies, development experts say.

"We need to mobilize the best scientists the world has to offer," said Kofi Annan, secretary-general of the United Nations, receiving the report on 25 June. Realizing the Promise and Potential of African Agriculture, was produced by the InterAcademy Council, an alliance of 90 scientific academies. It outlines ways in which scientists, farmers, industry and governments can work together to feed the 200 million malnourished people in Africa.

The academies propose that agricultural research should focus on the four farming systems that they think have the most potential: mixing maize and animals; combining cereals and roots; irrigated systems; and tree crops.

They urge African nations to support partnerships between publicly funded research groups and private companies to ensure, for example, that new strains of crops win market access. This is seen as essential in providing farmers with secure income and helping them to escape subsistence farming. The academies also call for the foundation of internationally funded 'centres of excellence' in Africa and for a doubling in the agricultural research spending of both African governments and donor agencies by 2015 .

Agricultural research experts broadly welcomed the attempt to shift public attention away from emergency famine responses towards securing Africa's food supply.

But some question how the recommendations will be translated into action and who is going to cough up the cash. "That," says
Yvette Stevens, a UN adviser on development in Africa, "is where these things drop dead."

Others point out problems with the specifics of the report. For example, scientists at the proposed centres might be more interested in publishing papers than addressing local problems, says Richard Jefferson, head of the Center for the Application of Molecular Biology to International Agriculture in Canberra, Australia.

Deeper problems in trade policy and African infrastructure need to be addressed before science can benefit farmers, say many development specialists. Agricultural subsidies in rich countries, for a start, make it almost impossible for African crops to compete on price, at home or abroad. "If there is one intervention that would transform Africa's potential," says Jefferson, "it would be the complete abandonment of agricultural subsidies."

Even when agricultural research succeeds in boosting crop yields, lack of roads and other basic infrastructure can prevent the resultant harvest getting to market. These issues need to be addressed alongside the scientific ones, says Peter Hartmann, director of the International Institute of Tropical Agriculture in Ibadan, Nigeria.

But Calestous Juma, a development specialist at Harvard University, welcomes the report and believes the next challenge is to convince the heads of African governments: "Without high-level political commitment there is not pressure to realize these goals."

The Forum for Agricultural Research in Africa is drawing up regional action plans based on the report, says Rudy Rabbinge, a development specialist at Wageningen University in the Netherlands and co-chair of the report panel. Annan will personally convey the findings to heads of state at the meeting of the African Union in Addis Ababa, which started this week.

\section{Research cloning gets green light from Japanese ethicists}

\author{
David Cyranoski, Tokyo
}

Japan looks set to end its bar on therapeutic cloning, giving it the chance to compete with Britain, China and similar countries in fast-moving areas of biology such as stem-cell research.

On 23 June, the bioethics committee of the Council for Science and Technology Policy, Japan's main scientific decisionmaking body, voted to lift a three-year moratorium on therapeutic cloning by ten votes to five. The main council is expected to endorse the decision shortly. But rules to govern the procedure, which the committee will have to clarify before research can go ahead, will probably take a year or more to establish.

Therapeutic cloning involves creating an embryo by transferring the nucleus from a patient's cell to an egg cell stripped of its own nucleus. This clone yields stem cells that can develop into any of the body's tissues and may have the potential to repair the patient's organs. It promises much, but opponents say the research is advancing too quickly given ethical questions over its use of human eggs.

Shin-ichi Nishikawa, a committee member and stem-cell biologist at RIKEN's Center for Developmental Biology in Kobe, voted for the change, but worries that no plan has been agreed to allow research to start. "Considering the slow speed of decision-making in Japan, it is difficult to forecast when actual experiments with nuclear-transfer stem cells will be allowed," he says.

However, fellow committee member Motoya Katsuki, director of the National Institute for Basic Biology in Okazaki, says that the scientific and ethical problems that caused the moratorium to be put in place have not been solved. Katsuki, an embryologist who works with mice as models, opposed the lifting of the moratorium and says that abnormalities in cloned animals are still not properly understood. This could lead to wasteful experiments on human eggs, he adds. "From an ethical perspective we should avoid experimentation on human specimens as much as possible."

Controversy over the vote could erode vital popular support. Those against lifting the ban say there was not sufficient time for discussion, and some media reports have described the decision as a "forced consensus".

Over the next two weeks, the bioethics committee is expected to work out how to implement its decision. 